\title{
A szegedi biotechnológiai vállalkozások tudáshálózata - a Biopolisz jelene
}

\section{The knowledge network of biotech firms in Szeged - Biopolis revisited}

\author{
GYURKOVICS JÁNOS, JUHÁSZ SÁNDOR
}

GYURKOVICS János: egyetemi tanársegéd, Szegedi Tudományegyetem, Gazdaságtudományi Kar, Közgazdaságtani és Gazdaságfejlesztési Intézet; 6722 Szeged, Kálvária sugárút 1.; gyujan@eco.u-szeged.hu; https://orcid.org/0000-0001-6731-7780

JUHÁSZ Sándor: tudományos segédmunkatárs, Magyar Tudományos Akadémia, Közgazdaság- és Regionális Tudományi Kutatóközpont, Agglomeráció és Társadalmi Kapcsolathálózatok Lendület-kutatócsoport; 1097 Budapest, Tóth Kálmán utca 4.; tudományos segédmunkatárs, Szegedi Tudományegyetem, Gazdaságtudományi Kar, Közgazdaságtani és Gazdaságfejlesztési Intézet; 6722 Szeged, Kálvária sugárút 1.; juhasz.sandor@krtk.mta.hu; https://orcid.org/0000-0003-3124-8597

KULCSSZAVAK: biotechnológia; tudáshálózat; növekedési pólus; Biopolisz

ABSZTRAKT: A fejlesztési pólusok koncepciója a hazai térségekben koncentrálódó tudásintenzív tevékenységek nyújtotta előnyök megerősitését és kiaknázását tűzte ki célul. Kutatás-fejlesztési, gazdasági és infrastrukturális adottságaik alapján tágabb térségüket dinamizálni képes pólusvárosokat és hozzájuk kapcsolódó húzóágazatokat jelöltek ki, így Szegeden a Biopolisz program keretében a biotechnológia került előtérbe. Az ágazat kiemelkedően jó térségi adottságai ellenére a szegedi Biopolisz program nem váltotta be a hozzá füzött reményeket.

Tanulmányunk célja, hogy a szegedi biotechnológiai cégek közötti tudáshálózat elemzése révén bemutassuk az iparági koncentráció mögötti együttműködéseket és reflektáljunk a Biopolisz program célkitüzéseire. Eredményeink alapján elmondható, hogy a relatíve sürü helyi kapcsolatháló ellenére magas innovációs és exportpotenciállal rendelkező vállalkozások kevésbé integrálódtak a lokális iparági tudáshálózatba. A kiemelt támogatás és figyelem ellenére az iparág látszólag kevésbé képes kihasználni a térbeli koncentráció és a kedvező helyi adottságok nyújtotta előnyöket, ami jelentőségének óvatosabb megítélését és a koncepció kritikáját vonja maga után.

János GYURKOVICS: lecturer, Institute of Economics and Economic Development, Faculty of Economics and Business Administration, University of Szeged; Kálvária sugárút 1., H-6722 Szeged, Hungary; gyujan@eco.u-szeged.hu; https://orcid.org/0000-0001-6731-7780

Sándor JUHÁSZ: junior research fellow, Institute of Economics, Centre for Economic and Regional Studies, Hungarian Academy of Sciences; Tóth Kálmán utca 4., H-1097 Budapest, Hungary; junior research fellow, Institute of Economics and Economic Development, Faculty of Economics and Business Administration, University of Szeged; Kálvária sugárút 1., H-6722 Szeged, Hungary; juhasz.sandor@krtk.mta.hu; https://orcid.org/0000-0003-3124-8597

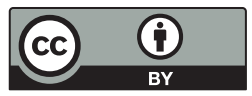


KEYWORDS: biotechnology; knowledge network; growth pole; Biopolis

\begin{abstract}
The concept of growth poles aimed to enhance and exploit the benefits arising from the geographical concentration of knowledge-intensive economic activities in Hungary. Based on research and development capabilities and economic and infrastructural characteristics, several cities were identified as growth poles and it was assumed that these cities and their key sectors could promote regional economic growth. Under the Biopolis programme, Szeged was chosen as a growth pole and biotechnology as a key industry. However, despite the area's outstanding features, the results of the Biopolis programme fell far short of expectations.

The aim of this study is to reflect on the objectives and results of the Biopolis programme and to analyse the patterns of collaboration in the knowledge network of biotechnology companies in Szeged. Our results suggest that despite the relatively dense local knowledge network, companies with higher innovation and export potential are less integrated into it. In spite of the greater support and attention for biotechnology in Szeged, biotech firms do not appear to be able to take advantage of the geographical concentration and favourable local conditions. Therefore, the importance of biotechnology as a key sector in this area should be treated with caution and the implementation of the Biopolis programme may require some criticism.
\end{abstract}

\title{
Bevezetés
}

A tudásintenzív iparágak térbeli koncentrációjából származó előnyök gazdaságfejlesztési célú kiaknázásának érdekében alakult ki hazánkban a fejlesztési pólusok koncepciója. Kutatás-fejlesztési, gazdasági és infrastrukturális szempontokat figyelembe véve kiemelkedő adottságokkal rendelkező, tágabb térségüket dinamizálni képes húzóágazatokat jelöltek ki Budapest mellett több vidéki nagyvárosban. A koncepció szerint a kijelölt pólusvárosokban elsősorban a magas hozzáadott értékeket előállító, tudásintenzív vállalkozások klaszteralapú fejlesztését ösztönözték, annak érdekében, hogy a klasztert alkotó vállalkozások, egyetemek és egyéb helyi szereplők egymással együttműködve képesek legyenek a globális versenybe bekapcsolódni és ott helytállni (Lengyel 2007).

A növekedési pólusok alapját a tudásalapú tevékenységek térbeli koncentrációja képezi (Faragó, Lux 2014; Lengyel 2007). A kevésbé fejlett régiók növekedési pólusaiban olyan innovatív klaszterek és speciális üzleti környezet kialakítása és fejlesztése kívánatos, ahol az innovációhoz szükséges tudás a térben koncentrálódó szereplők között szabadon tud áramlani. Emiatt a pólusprogram elsősorban a támogató üzleti környezet fejlesztésére helyezte a hangsúlyt, a földrajzi koncentrációból eredő, tudástúlcsordulásból származó előnyök kiaknázása érdekében (Lengyel 2007). A közelmúltban azonban számos kutatás rávilágított arra, hogy az iparági tudás „nincs a levegőben”, így önmagában az iparági koncentrációhoz tartozás nem elegendő az innovációhoz szükséges tudás megszerzéséhez (Boschma, Ter Wal 2007; Giuliani, Bell 2005; Giuliani 2007). Sokkal inkább a helyi szereplők közötti társadalmi hálózatokban, a bizalmon alapuló szakmai kapcsolathálókban való részvétel a fontos (Maskell, Malmberg 1999). Annak ellenére azonban, hogy Fekete $(2008,511$.$) szerint a$ 
„kapcsolatfejlesztés a póluskoncepció kiemelt eleme lett”, valójában a gazdasági szereplők közötti együttműködések szükségessége csak közvetett módon jelent meg a pólusprogramban.

A vizsgálatunk fókuszában álló szegedi pólusprogram (Biopolisz program) keretében a biotechnológián alapuló iparágak fejlesztését tűzték ki célul (Szeged Pólus 2005). A biotechnológia számos kedvező adottsággal rendelkezik a térségben. Az élettani és biológiai kutatásnak és oktatásnak komoly hagyományai vannak, jelentős a kutatói és infrastrukturális kapacitás és relatíve erős a biotechnológiai vállalkozások térbeli koncentrációja. A pólusprogram elindulása óta eltelt több mint tíz év eredményei alapján azonban elmondható, hogy az ágazat kiemelkedően jó térségi adottságai ellenére a szegedi Biopolisz program nem váltotta be a hozzá füzött gazdaságfejlesztési várakozásokat. A biotechnológia nem vált a térség gazdaságát dinamizálni képes húzóágazattá, ténylegesen működő klaszter nem alakult ki.

A probléma egy lehetséges okára a Biopoliszhoz kapcsolódó kutatásában már Schulz (2012) is felhívta a figyelmet, miszerint a szegedi biotechnológia esetében csak látens klaszterről beszélhetünk, mivel a térben sűrűsödő vállalkozások és kapcsolódó intézmények között csupán gyenge kollaboráció figyelhető meg. A földrajzi koncentrációból fakadó előnyök kiaknázásához fontos a vállalkozások és a szervezetek közötti együttműködés, amelynek hiányát Schulz (2012) a szegedi biotechnológiai klaszter fejlődésének egyik fó akadályaként azonosítja. A tényleges kapcsolatok feltárására viszont ez idáig nem került sor, pedig a tudásáramlás hálózatainak tanulmányozása révén jobban megérthetnénk a klaszterek formálódása és sikeressége mögötti okokat (Juhász, Elekes, Gyurkovics 2016; Juhász, Lengyel 2016a, 2016b; Ter Wal, Boschma 2009).

A gazdasági szereplők közötti kapcsolatok feltárásának egyik lehetséges módja a társadalmi hálózatelemzés. Jelen kutatás célja - a szegedi biotechnológiához kapcsolódó fejlesztési elképzelésekre reflektálva -, hogy feltárja a szegedi biotechnológiai vállalkozások közötti együttműködéseket és egyszerủ hálózatelemzési eszközökkel bemutassa a tudás- és ismeretáramlás helyi iparági kapcsolatrendszerét. A kérdőíves megkeresésből származó, cégszintű kapcsolati adatok alapján szemléltetjük az iparág jelenlegi helyi kapcsolatait és az együttműködő szervezetek főbb ismérveit. Majd a kutatás eredményeit a Biopolisz programmal összevetve néhány megállapítással élünk.

A tanulmány elején röviden bemutatjuk a pólusprogramot, áttekintjük a koncepció fontosabb szakirodalmi vonatkozásait, valamint a klaszterek és helyi iparági tudáshálózatok elemzéséhez kapcsolódó irodalmakat. Ezt követően a vizsgálat kontextusát, a szegedi biotechnológiát és a Biopolisz programot ismertetjük részletesebben, majd kutatásunk és ezen belül az adatgyüjtés módszertanát mutatjuk be. Majd eredményeinket összegezzük, végül tanulmányunk - a vizsgálati korlátok és a további lehetséges kutatási irányok áttekintése után - a szegedi biotechnológiához kapcsolódó fejlesztési tervek óvatos kritikájával zárul. 


\section{Elméleti alapok}

\section{A pólusprogram és ami mögötte van}

A tudásintenzív gazdasági tevékenységek térbeli koncentrációjából származó előnyök felismerése a gazdaságfejlesztési beavatkozásokban - így az EU megújított lisszaboni stratégiájában és a 2007-2013-as programozási időszak irányelveiben is - tetten érhető (Lengyel 2007). Az irányelvek között szerepelnek a fejlesztési pólusok, melyek lényege, hogy a térben koncentrálódó, hasonló iparágba tartozó innovatív vállalatok és kapcsolódó intézmények között partnerség alakul ki. Hazánkban a fejlesztésipólus-elképzelés az Országos területfejlesztési koncepcióban (OTK) fogalmazódott meg 2005-ben. A koncepcióban - a meglévő kutatás-fejlesztési, gazdasági és infrastrukturális adottságaik alapján - a tágabb térségüket dinamizálni képes pólusvárosokat és a hozzájuk kapcsolódó húzóágazatokat jelölték ki. Az OTK „Budapestet és agglomerációját kiemelt fejlesztési pólussá, Debrecen, Győr, Miskolc, Pécs, Szeged városokat fejlesztési pólussá, Székesfehérvár és Veszprém városát fejlesztési társközponttá jelölte ki." (96/2005. országgyűlési határozat). 2006-ra elkészültek a pólusvárosok stratégiai tervei, majd a 2007-2013-as programozási periódus keretében és finanszírozásával elindult az úgynevezett pólusprogram. A program segítségével az egyes pólusvárosokban eltérő gazdasági ágak fejlesztése indult meg, így került középpontba Szegeden az egészségipari, környezetipari és agrárgazdasági biotechnológia.

A pólusprogram keretében voltaképpen regionális klaszterek innovativitásának és exportképességének fejlesztését tűzte ki a kormány (Pólus Programiroda 2008). A program egyértelmű célja volt olyan nemzetközileg is versenyképes klaszterek kialakítása, melyek később képesek a pólusvárosok és régióik gazdaságának versenyképességét és üzleti környezetét megerősíteni. E célkitűzések a pályázati felhívások szintjén is megjelentek a hazai fejlesztéspolitikában. A pólusprogramhoz kapcsolódóan a klaszterfejlesztés négy szintjét különítették el: a regionális operatív programokból finanszírozott induló és fejlődő klaszterek, valamint a gazdaságfejlesztési operatív programból finanszírozni kívánt akkreditált és pólusinnovációs klaszterek (KSH 2010). A klaszterfejlesztés végül nem váltotta be a hozzá füzött reményeket: a tervezett 5-10 pólusklaszterből egy sem jött létre.

A pólusprogram elméleti alapjának a tudásalapú agglomerációs gazdaságok, a növekedési pólusok és a klaszterek szakirodalmát tekinthetjük (Faragó, Lux 2014; Lengyel 2007). A tudásalapú gazdaságban egyre fontosabbá válik a régiók közötti munkamegosztás, melynek nyertesei főként a tudásintenzív tevékenységek térbeli koncentrációjával rendelkező térségek (Varga 2004). A fejlesztési pólusok gondolata - így a pólusprogram koncepciója is - azon alapul, hogy a térben koncentrálódó, tudásalapú gazdasági tevékenységek támogatásával egy-egy kiemelt központ fejlesztése a tágabb térségére is kedvezően hat 
(Barta, Lengyel 2007). E gondolatok a francia gyökerű növekedésipólus-elméletből építkeznek. Eszerint a tudásintenzív ágazatokat tömörítő központok olyan területi növekedési csomópontként funkcionálnak, melyek különböző agglomerációs hatások révén a hierarchia alacsonyabb szintjein lévő településekben is növekedési folyamatokat generálnak (Boudeville 1966; Lengyel, Rechnitzer 2004). A növekedés alapját a pólusokban müködő iparági és regionális klaszterek jelentik, melyek innovativitásuk révén hatást gyakorolnak a regionális növekedésre (Lengyel, Rechnitzer 2004). Emiatt egy növekedési póluson belül meghatározó tényező az innovációhoz szükséges tudás elérhetősége és áramlása a szervezetek között.

A pólusprogramban megfogalmazottak összecsengenek Marshall (1920) gondolataival az iparági tudástúlcsordulásról. Állítása szerint az iparági tudás túlcsordulása révén az egyazon térségben tevékenykedő vállalkozások között az információ, a tapasztalat és a rejtett tudás szabadabban tud áramlani, elősegítve ezzel az új termékkombinációk megjelenését, az innovációt. Az elmélet szerint e hatások megjelenésével olyan öngerjesztő folyamat indul be, amely tovább növeli az iparág térbeli koncentrációját. Ezzel olyan támogató üzleti környezet, helyi versenyelőny alakul ki, amely meghatározza a vállalkozások sikerességét.

\section{A helyi tudáshálózatok jelentősége}

A pólusprogram gazdaságfejlesztési koncepciójának középpontjába tehát a térségek exportképes iparágainak megerősítése került, nemzetközi szinten versenyképes klaszterek kialakítása révén. A klasztert alkotó vállalkozások jelentős innovációs képességgel rendelkeznek, ami a nemzetközi versenyben való helytállásukhoz nélkülözhetetlen (Porter 1990). A klaszterhez tartozó vállalatok innovativitását kezdetben a térbeli közelséggel összefüggő pozitív extern hatásokkal, így a helyi tudástúlcsordulással magyarázták (Audretsch, Feldman 1996; Jaffe, Trajtenberg, Henderson 1993). Később azonban több tanulmány is rávilágított arra, hogy önmagában a szereplők földrajzi közelsége nem elegendő a tudás helyi áramlásához és az innovációhoz (Boschma 2005; Lengyel, Fenyővári, Nagy 2012). A klaszterek sikerességét a klasztert alkotó vállalkozások közötti kapcsolatok, a szereplők helyi hálózatokba való beágyazottsága jelentősen befolyásolja (Giuliani 2010; Ter Wal, Boschma 2009). A személyes kapcsolatokon alapuló együttműködések révén ugyanis csökkenthetők a tranzakciós költségek és növelhető a kölcsönös tanulás hatékonysága (Borgatti et al. 2009; Maskell, Malmberg 1999).

A tudástúlcsordulás kialakulásában és a tanulás folyamataiban a tudáshálózatoknak van jelentős szerepük. A tudáshálózatok az innovációhoz kapcsolódó tudás átadása és a komplex technológiai problémák közös megoldása révén kötik össze a cégeket (Giuliani 2010). Szélesebb kontextusban a tudásáramlás kapcsolatainak feltérképezése és elemzése segít megismerni a régió iparági és 
innovációs környezetét, a tudás cégek közötti áramlását és a vállalatok társadalmi-gazdasági beágyazódását (Juhász, Lengyel 2016a).

A klaszterek mögötti tudáshálózatok közvetlen feltérképezéséhez a társadalmi hálózatelemzés módszertanát már több esetben sikeresen alkalmazták. A chilei borklaszterek elemzése során Giuliani és Bell (2005) kutatása rámutatott arra, hogy az iparági klaszterekben való részvétel önmagában nem biztosítja a vállalkozások hozzáférését a - térségi koncentráció révén felhalmozódott szakmai tudáshoz és információhoz. A tudás „nincs a levegőben”, ahhoz csupán a tudásáramlás társas hálózataiban való aktív részvétellel férhetnek hozzá a cégek. Boschma és Ter Wal (2007) vizsgálata azt mutatta ki, hogy a klaszterek helyi tudáshálózataiban elfoglalt jelentősebb pozícióhoz jellemzően magasabb innovációs teljesítmény is párosul.

A helyi tudásmegosztás mellett nagy jelentősége van a cégek térségen kívüli kapcsolatainak, melyeken keresztül új szakmai ismeret, technikai tudás juthat a klaszterbe Juhász, Lengyel 2016b). A folyamatos megújulás, a technológiai bezáródás elkerülése és a hosszú távú versenyképesség érdekében a helyi kooperáció mellett a térségen kívülre irányuló szakmai kapcsolatok is szükségesek (Bathelt, Malmberg, Maskell 2004).

A vállalkozások sikerességét befolyásolja a helyi tudáshálózatokban való aktív részvételük. A pólusprogram megvalósítása során az üzleti környezet infrastrukturális elemeinek javításával inkább a földrajzi koncentráció megerősítése került előtérbe, míg a hálózatosodás, a beágyazódottság és az informális kapcsolatok fontossága csekély figyelmet kapott. Ez lehet az egyik fontos oka a kezdeményezés mérsékelt sikerességének.

\section{A szegedi biotechnológia}

Az elmúlt két évtizedben mind hazai, mind nemzetközi színtéren kiemelt figyelem irányult a biotechnológiára mint új iparágra, mivel eredményeihez kötődöen más iparágakban is jelentős technológiai újdonságok születtek. Az iparág tudásintenzív jellegéből adódóan folyamatos az innovációs kényszer, a vállalkozások kiterjedt kutatás-fejlesztési tevékenységet folytatnak (Szakálné Kanó, Vas 2013). A biotechnológiával foglalkozó cégek döntően magas hozzáadott értékủ termékeket és szolgáltatásokat állítanak elő és globálisan versengenek (Schulz 2012), így főként magasan képzett munkavállalókat alkalmaznak, akik átlagon felüli bérezésben részesülnek.

Szeged térsége számos olyan egyedi jellemzővel rendelkezik, amely kedvező feltételeket teremtett a biotechnológia húzóágazatként történő kijelöléséhez. A felsőfokú végzettséggel rendelkezők aránya (19,53\%) 5 százalékponttal haladja meg az országos átlagot. Ezen belül a biológiai, kémiai és orvosi területeken tudományos minősítéssel rendelkezők száma is országos átlag feletti 
(Lengyel 2007). A Szegedi Tudományegyetem évszázados kutatási és oktatási tevékenysége mellett több száz, a tudományterülethez kapcsolódó foállású kutatót foglalkoztat a Magyar Tudományos Akadémia Szegedi Biológiai Kutatóközpontja (SZBK), valamint a Bay Zoltán Alkalmazott Kutatási Közhasznú Nonprofit Kft. Biotechnológiai divíziója (Bay-Bio). Országos összehasonlításban Szegeden a 72.11 Biotechnológiai kutatás, fejlesztés TEÁOR'08 kóddal jelzett vállalkozások relatív erős koncentrációja figyelhető meg (Schulz 2012). Szükséges megemlítenünk, hogy e vállalkozások többsége a biotechnológia eltérő részterületeire, különböző szektorok igényeire specializálódott. A cégek termékeikkel, szolgáltatásaikkal jellemzően az orvosi, agrár-, környezetvédelmi iparágakhoz és a gyógyszergyártáshoz kapcsolódnak. Összességében a kedvező kutatás-fejlesztési és infrastrukturális adottságok, a magasan képzett helyi szakemberek és a biotechnológiával foglalkozó vállalkozások relatív térbeli koncentrációja tette ígéretessé a biotechnológiai iparág fejlesztését Szegeden, mely a Biopolisz program 2005. évi megszületéséhez vezetett.

A Biopolisz program négy, többnyire egymásra épülő célkitűzést fogalmazott meg (Szeged Pólus 2005):

- Tudásintenzív, magas hozzáadott értékkel rendelkező helyi gazdaság létrehozását tűzte ki célul, amely a térség tudományos kapacitásaira építve tudásintenzív kis- és középvállalatokból, kutatóintézetekből létrejövő spin-off cégekből és biotechnológiai nagyvállalatok kihelyezett részlegeiből alakul ki. A biotechnológiai cégek térbeli koncentrációjának növelése volt a cél, segítve egy regionális klaszter kialakulását. Ennek keretében további kapcsolódó vállalkozások létrejöttére számítottak, melyek a biotechnológia eredményeit hasznosítva képesek a térség gazdaságának dinamizálására.

- A Biopolisz program második célkitűzése a térség foglalkoztatottságának bővítése volt, melyet a térségen kívüli jövedelmek vonzásával, a biotechnológiai vállalkozások exportorientáltságának javításával és a biotechnológiához kapcsolódó vállalkozások betelepítésével kívántak elérni.

- Harmadik célkitüzésként a tágabb térség - biotechnológia által generált - gazdasági szerkezetváltását kívánták elősegíteni.

- Végül, a negyedik célkitűzés Szeged európai városhálózatba történő integrálódását igyekezett előmozdítani - a Biopolisz program során kialakuló nemzetközi kapcsolatok révén.

Összességében a célok csak részlegesen illeszkedtek a helyi adottságokhoz. A koncepció kidolgozása során - a klaszteralapú gazdaságfejlesztés szempontjából kulcsfontosságú - több szempontot figyelmen kívül hagytak: így például a kritikus tömeg hiányát, a helyi kapcsolatok feltérképezését vagy a koncentráció szektorális széttagoltságát. 


\section{Adatgyüjtés és módszertan}

Kutatásunkhoz vállalati szintű adatokat használtunk, amelyeket kérdoíves felmérés segítségével gyüjtöttünk 2016 decemberében. Vizsgálatunk kettős fókuszú volt. Egyrészt a vállalatok innovációs teljesítményére és az ehhez kapcsolódó szervezeti adottságaira voltunk kíváncsiak, így többek között a $\mathrm{K}+\mathrm{F}$-projektek és a szabadalmak számára, valamint a munkavállalók iskolai végzettségére kérdeztünk rá.

Másrészt érdeklődésünk középpontjában a szervezetek közötti ismeretáramlásra és segítségnyújtásra vonatkozó kapcsolatok álltak, amelyeket a listás lekérdezés módszerével mértünk fel (Ter Wal, Boschma 2009; Wasserman, Faust 1994). Minden megkérdezett cég teljes listát kapott a térségben található összes, biotechnológiai kutatást végző szervezetről, és a megadott kérdés alapján a velük kialakult kapcsolataikat kellett értékelniük.

A tudáshálózat feltárásához szükséges kapcsolati adatok gyüjtéséhez az alábbi - számos hasonló tanulmányban sikerrel használt (Boschma, Ter Wal 2007; Giuliani, Bell 2005; Juhász, Lengyel 2016a; Morrison 2008) - kérdést tettük fel:

„Ha szakmai tanácsra vagy technikai segitségre van szüksége, mely helyi vállalatokhoz vagy szervezetekhez fordul az alábbiak közül? [Kérem, értékelje a megállapitott kapcsolatok jelentöségét minden egyes cégre vonatkozóan - a tartósságot és minőséget

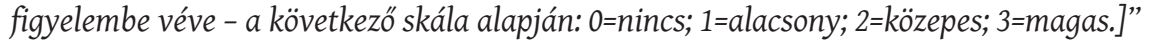

A kérdés az innovációhoz kötődő tudásátadást méri és csupán a térségen belüli, vállalkozások közötti együttműködéseket tárja fel. Kérdésünk a közös problémamegoldásra és a technikai segítségnyújtásra irányul, mivel ezek szorosan kötődnek a gazdasági tevékenység átalakulásához, a cég fejlődéséhez (Giuliani, Bell 2005). Túlmutat a puszta információcsere csatornáinak feltérképezésén, és a komplex tudás átadását próbálja megragadni, amely lehet például egy kísérleti technikához kapcsolódó tapasztalat megosztása vagy egy új eljárás ismertetése.

A válaszokból $n \times n$ mátrixot készítettünk, ahol $n$ a válaszadó vállalkozások száma), melyben minden cella a tudásátadás meglétét jelöli az $i$-edik sorban lévő cégtől a j-edik oszlopban lévő cég irányába. Ennek értelmében az $(i, j)$ cellában akkor áll 0-tól különböző szám, ha $i$ cég tudást adott át $j$ cégnek legalább 1-es súlyozással. Az $(i, j)$ cella 0-t tartalmaz, amennyiben az $i$ és a j cégek között nem történt tudásátadás. Mindezek eredményeként egy irányított, súlyozott mátrixot kaptunk.

A vizsgálat során megpróbáltuk elérni az összes, biotechnológiával foglalkozó szegedi társas vállalkozást. A cégek azonosításához a Bisnode online adatbázisára támaszkodtunk. Az adatbázis az összes magyarországi vállalkozás céginformációs adatait, fo" tevékenységi területét, árbevételét és foglalkoztatotti létszámát tartalmazza. Végső mintánkat az a 18 cég képezte, amelyek a TEÁOR'08 72.11 Biotechnológiai kutatás, fejlesztés szakágazatba sorolódtak, szegedi székhellyel rendelkeztek, valamint foglalkoztatotti létszámuk 2015-ben meghaladta a 2 főt. Kérdőívünket minden esetben a vállalkozások ügyvezetőivel vagy a szakmai irányítást, felügyeletet végző munkatársaival töltettük ki. 
Az azonosított 18 vállalkozásból 12 töltötte ki kérdőívünket. A segítségnyújtásra és ismeretáramlásra vonatkozó kérdésünkhöz kapcsolódó lista végén egy nyitott kérdéssel további, a listában nem szereplő szervezetek bevonását is lehetővé tettük, azonban egyetlen szervezet sem jelölt meg további térségi biotechnológiai szereplőt. Azon cégek, amelyeket nem tudtunk elérni, döntően mikro- vagy kisvállalkozások. A kérdőíves megkérdezés alapján egy irányított hálót alkottunk 12 csomóponttal és 45 éllel.

A hálózat strukturális jellemzőit és a válaszadó szervezetek innovációs és kutatás-fejlesztési tevékenységének mintázatait a következő fejezetben mutatjuk be.

\section{Eredmények}

A válaszadók statisztikai adatai alapján látható, hogy csupán két vállalkozás foglalkoztatottjainak száma haladja meg a 25 föt, és túlnyomó többségük éves nettó árbevétele nem éri el az 500 millió forintot (1. táblázat). A minta alapján az iparág érettnek mondható. A vizsgált vállalkozások átlagos életkora közel 11 év. Az árbevételi lista elején főleg az idősebb vállalkozások állnak. Várakozásainkkal és a Biopolisz programban megfogalmazott célokkal ellentétben a cégek többsége kevésbé intenzív exporttevékenységet folytat, a kitöltők több mint fele egyáltalán nem értékesít külföldre, csupán egyetlen cég fókuszál kizárólagosan a nemzetközi piacra. Szektorálisan a vállalkozások többsége a gyógyszeriparhoz kapcsolódik. Mindössze 5 vállalkozást találtunk, melyek más szektorokkal (pl. agrárium, környezetvédelem) állnak elsősorban kapcsolatban. A vállalkozások tudásintenzív jellegét jól mutatja, hogy a cégek költségeinek túl-

1. táblázat: A szegedi biotechnológiai cégek általános jellemzői (2015) Characteristics of biotechnological firms in Szeged (2015)

\begin{tabular}{lccccc}
\hline Cég & $\begin{array}{c}\text { Statisztikai létszám } \\
(f o ́)\end{array}$ & Életkor (év) & $\begin{array}{c}\text { Árbevétel-kategória } \\
(\text { millió Ft) }\end{array}$ & $\begin{array}{c}\text { Az export aránya } \\
\text { az árbevételból (\%) }\end{array}$ & $\begin{array}{c}\text { K+F-költségek } \\
\text { aránya (\%) }\end{array}$ \\
\hline B1 & 2 & 3 & $<100$ & 0 & 50 \\
B2 & 8 & 13 & $100-500$ & 15 & 80 \\
B3 & 15 & 16 & $100-500$ & 10 & 75 \\
B4 & 150 & 25 & $500<$ & 5 & 95 \\
B5 & 3 & 11 & $100-500$ & 0 & 90 \\
B6 & 2 & 6 & $<100$ & 0 & 30 \\
B7 & 2 & 8 & $<100$ & 0 & 70 \\
B8 & 74 & 17 & $500<$ & 100 & 25 \\
B9 & 4 & 5 & $<100$ & 0 & 100 \\
B10 & 4 & 11 & $100-500$ & 10 & 90 \\
B11 & 6 & 10 & $100-500$ & 0 & 100 \\
B12 & 14 & 6 & $100-500$ & 0 & 100 \\
\hline
\end{tabular}


nyomó része a kutatás-fejlesztéshez kapcsolódik. A megkérdezettek között csupán 2 vállalkozás van, amelyeknél a K+F-költségek aránya nem éri el az 50\%-ot a vállalkozás költségszerkezetében. Egyikük, B6 a mintában szereplő egyik legkisebb vállalkozás ( 2 fó foglalkoztatotti létszámmal és 100 millió forint alatti árbevétellel), másikuk pedig B8, amelyik teljes, 500 millió Ft feletti éves árbevételét külföldi piacokról szerzi. Mindez azt is jelenti, hogy a szegedi biotechnológiai vállalkozások exportorientáltsága nem feltétlenül függ össze kutatási-fejlesztési tevékenységük mértékével.

A szegedi biotechnológiai vállalkozások tudásintenzív jellegéről elmondható, hogy a cégek háromnegyede rendelkezik szabadalommal, fele többel is (2. táblázat). A szabadalmakat és az életkort összevetve azt is megfigyelhetjük, hogy az iparág jellegzetességeiből adódóan az idősebb vállalkozásoknak van több szabadalmuk. Szinte minden vállalkozás részt vesz K+F-projektekben, és a cégek többsége - legalább 50\%-ban - doktori fokozattal rendelkező munkavállalókat foglalkoztat. A szabadalmak megjelenése, a K+F-projektek magas száma és a magasan képzett munkavállalók jelentős aránya jól mutatja, hogy a cégek többsége kutatás-fejlesztés központú, tudásintenzív tevékenységet folytat, és e kapacitások kiépítéséhez időre volt szükség. A K+F-en alapuló innováció jelentőségét jól szemlélteti továbbá, hogy az új termék bevezetéséből származó árbevétel aránya a legtöbb cégnél meghaladja a 15\%-ot. Összességében tehát a válaszadó cégeket tudásintenzív kis- és közepes vállalkozásokként jellemezhetjük, hasonló szektorális fókusszal, relatíve erős innovációs és kutatás-fejlesztési potenciállal, azonban a nemzetközi piacok felé csekély nyitottsággal.

A Biopolisz program innovatív, exportorientált biotechnológiai klaszter létrehozását tűzte ki célul. Az eredmények azt mutatják, hogy a cégek kiterjedt $\mathrm{K}+\mathrm{F}$-tevékenységet folytatnak, de ez gyakran nem eredményez értékesíthető új

2. táblázat: A szegedi biotechnológiai cégek innovativitása Innovativeness of biotechnological firms in Szeged

\begin{tabular}{lcccc}
\hline Cég & $\begin{array}{c}\text { Szabadalmak } \\
\text { száma }(d b)\end{array}$ & $\begin{array}{c}\text { K+F-projektek } \\
\text { száma }(d b)\end{array}$ & $\begin{array}{c}\text { Doktori fokozattal rendelkezón } \\
\text { munkavállalók aránya (\%) }\end{array}$ & $\begin{array}{c}\text { Új termék bevezetéséból } \\
\text { származó árbevétel aránya }(\%)\end{array}$ \\
\hline B1 & 0 & 5 & 0 & 0 \\
B2 & 1 & 8 & 50 & 15 \\
B3 & 2 & 3 & 50 & 15 \\
B4 & 4 & 12 & 30 & 20 \\
B5 & 1 & 2 & 100 & 0 \\
B6 & 0 & 1 & 50 & 0 \\
B7 & 0 & 0 & 0 & 10 \\
B8 & 3 & 20 & 40 & 30 \\
B9 & 1 & 2 & 75 & 0 \\
B10 & 3 & 4 & 20 & 50 \\
B11 & 2 & 0 & 30 & 40 \\
B12 & 3 & 2 & 50 & 100 \\
\hline
\end{tabular}


terméket. És ahol relatíve magasabb az új termék értékesítéséből származó árbevétel aránya, ott a vállalkozások inkább a hazai piacot részesítik előnyben.

Vizsgálatunk középpontjában a szegedi biotechnológiai cégek tudáshálózatának feltérképezése és elemzése áll, ugyanis számos esetben beigazolódott, hogy a biotechnológiai iparág kezdeti fejlődésében óriási jelentősége van a klaszteren belüli - intenzív helyi tudásátadáson alapuló - kapcsolatoknak (Feldman 2001; Zucker, Darby, Brewer 1998). A tudáshálózat vizsgálatával képet tudunk alkotni a szegedi biotechnológiai cégek közötti tudásáramlás mintázatairól. A szegedi biotechnológiai klaszter és így a Biopolisz program sikerességéhez a helyi szereplők közötti szoros kapcsolatok szükségesek.

A 12 válaszadó vállalkozás között 45 kapcsolatról adhatunk számot, ami az összes lehetséges kapcsolat 34\%-a. A hálózat - kis méretét és elszigetelt pontjait is figyelembe véve - relatíve sürünek tekinthető. Az általunk vizsgált vállalkozások átlagosan 3-4 helyi, biotechnológiával foglalkozó szervezettel állnak szakmai, technikai segítségnyújtáson alapuló kapcsolatban. A gráfot 3 komponens alkotja, mivel a 10 céget összetartó kapcsolatrendszer mellett 2 cég elszigetelt pontként jelenik meg, azaz egyáltalán nem cserél szakmai tudást más helyi biotechnológiai cégekkel. Ennek az lehet az oka, hogy míg az egyik cég a mintában szereplő legújabb vállalkozás, a másik profilját tekintve nem kapcsolódik a minta többségét jellemző gyógyszeripari tevékenységhez. A vállalkozások kapcsolatainak száma (fokszáma), azaz a csomópontból kiinduló élek száma (Dusek, Kotosz 2016), valamint azok irány szerinti megoszlása alapján a legtöbb kapcsolattal rendelkező 4 cég esetében a kifelé irányuló kapcsolatok száma magasabb, mint a befelé irányuló kapcsolatoké, azaz a hálózat kiemelkedő szereplői több szakmai segítséget kérnek, mint nyújtanak (3. táblázat).

Kutatásunk első lépéseként, a Biopolisz program céljaival összhangban, a szegedi biotechnológiával foglalkozó vállalkozások tudáshálózatát vetettük

3. táblázat: Szegedi biotechnológiai vállalkozások tudáshálózatbeli kapcsolatai Number of links in the knowledge network of biotechnological firms in Szeged

\begin{tabular}{|c|c|c|c|}
\hline Cég & Fokszám & A befelé irányuló kapcsolatok száma & A kifelé irányuló kapcsolatok száma \\
\hline B1 & 0 & 0 & 0 \\
\hline B2 & 16 & 7 & 9 \\
\hline B3 & 14 & 5 & 9 \\
\hline B4 & 5 & 5 & 0 \\
\hline B5 & 10 & 4 & 6 \\
\hline B6 & 10 & 3 & 7 \\
\hline B7 & 0 & 0 & 0 \\
\hline B8 & 9 & 6 & 3 \\
\hline B9 & 4 & 3 & 1 \\
\hline B10 & 8 & 5 & 3 \\
\hline B11 & 7 & 4 & 3 \\
\hline B12 & 7 & 3 & 4 \\
\hline
\end{tabular}


össze a hálózat szereplőinek külföldi kapcsolataival (1. ábra). A csomópontok mérete a cégek kapcsolatainak számával (fokszámával) arányos, valamint szürkével jelöltük a legalább 5 külföldi vállalkozással tudáscserét folytató szervezeteket. Az irányított élek a szakmai segítségkérés irányát mutatják. Amellett, hogy a biotechnológiai klaszterek kezdeti fejlődésében kiemelt szerepet játszik a helyi kapcsolatokon keresztül megvalósuló tudásáramlás (Feldman 2001; Zucker, Darby, Brewer 1998), a nem high-tech iparágakat koncentráló térségek biotechnológiai klasztereinek esetében a térségen kívülről érkező tudás integrálása alapvetően meghatározza a klaszter fejlődését (Trippl, Tödtling 2007). Ennek ellenére kutatásunk során azt láthatjuk, hogy a számos külső kapcsolattal rendelkező szervezetek kevésbé domináns szerepet töltenek be a helyi hálózatban, azaz a legtöbb kívülről érkező új tudáshoz kevés más helyi partner fér közvetlenül hozzá. Mindez meglepő, mert e szervezetek mindegyike a helyi iparág magját alkotó gyógyszeripari biotechnológiai tevékenységet folytató cégek közé tartozik.

A helyi tudáshálózat kevésbé összetartó jellege mellett a cégek 75\%-a rendelkezik legalább egy, a térségen kívüli tudásáramlást biztosító kapcsolattal, azaz a térségi cégek döntő többsége közvetlenül hozzáfér térségen kívüli szaktudáshoz is. A külső kapcsolatok jelentőségét a szegedi biotechnológia esetében jól szemlélteti, hogy míg a helyi hálózatban összesen 45 kapcsolat volt kimutatható, térségen kívülre 43 kapcsolatot jeleztek a kérdőívben megkérdezettek. Ezek alapján elmondható, hogy a szegedi biotechnológia a nemzetközi verseny résztvevője, ami összhangban van a Biopolisz program céljaival. Azonban a helyi

1. ábra: Szegedi biotechnológiai vállalkozások külföldi kapcsolatainak száma és tudáshálózati pozíciója

Number of international connections and network position of the biotechnological firms in Szeged

(B1)
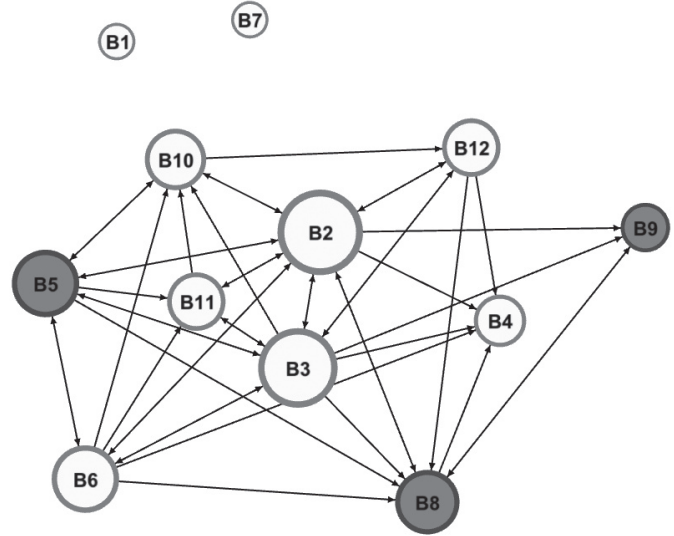

Megjegyzés: A csomópontok mérete azok fokszámával arányos, míg színük a külföldi kapcsolataik számát reprezentálja (szürke: legalább öt külföldi kapcsolat; fehér: kevesebb mint öt külföldi kapcsolat). 
együttmüködés nem eléggé intenzív, ami gátolja a megszerzett külső tudás áramlását a térségi szereplők között.

Változatlan hálózati szerkezet mellett vizsgáltuk a vállalkozások innovációs teljesítményét is, melyet összevetettünk hálózati pozíciójukkal (2. ábra). Az innovációs teljesítményt - a közösségi innovációs felmérés (EC 2014) módszertana alapján - az új termék bevezetéséből származó árbevétel arányával mértük. Ennek felméréséhez a vállalkozásoknak arról kellett számot adniuk, hogy 2014 és 2016 között bevezetett új termék vagy szolgáltatás értékesítéséből származó tárgyévi árbevételük mekkora részt tett ki a vállalkozás tárgyévi teljes árbevételében. Megkülönböztettük azon cégeket, melyek árbevételének legalább 20\%-át új, innovatív termékek értékesítéséből származó bevételek adták. Az innovatív termékek, szolgáltatások piaci értékesítésében a helyi hálózatban a legtöbb kapcsolattal rendelkező szereplők nem voltak kiemelkedőek, ami arra utal, hogy a helyi kapcsolatok csak mérsékelten befolyásolták a vállalkozások innovációs teljesítményét. A vállalat életkorával összevetve az innovatív termékek bevezetéséből származó árbevétel arányát azt láthatjuk, hogy a második legidősebb (B8) vállalkozáson kívül a többi cég az iparág relatíve fiatalabb szereplője. Feltehetően ezek a vállalkozások egy-egy meghatározó tudományos eredmény felhasználásából szerzik jövedelmük jelentős részét.

Ha megvizsgáljuk a kapcsolatok irányultságát is (3. táblázat), akkor megfigyelhetjük, hogy a magasabb innovációs teljesítménnyel rendelkező vállalkozásoknak - a B12-es vállalkozást leszámítva - több a befelé, mint a kifelé irányuló kapcsolatuk; a vállalkozások a helyi hálózaton belül inkább segítséget nyújta-

2. ábra: Szegedi biotechnológiai vállalkozások új termék bevezetéséből származó árbevételének aránya és tudáshálózati pozíciója

Revenues from new products and network position of the biotechnological firms in Szeged

(B1)

(B7)

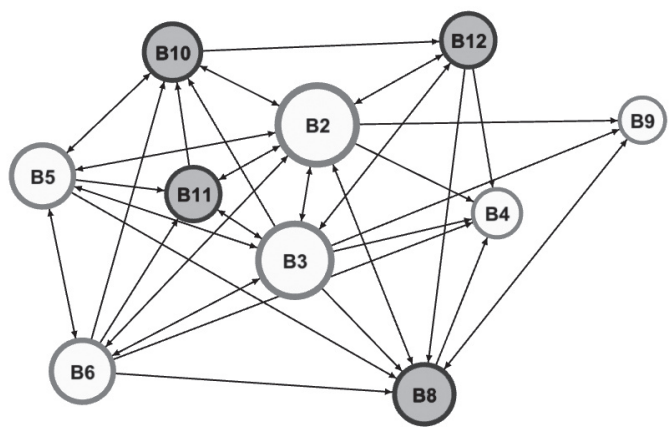

Megjegyzés: A csomópontok mérete azok fokszámával arányos, míg színük az új termék bevezetéséból származó árbevétel arányát reprezentálja (szürke: az új termék bevezetéséból származó árbevétel aránya legalább 20\%; fehér: az új termék bevezetéséboól származó árbevétel aránya alacsonyabb, mint 20\%). 
nak, semmint segítséget kérnek. Ezzel szemben a szegedi biotechnológiai klaszter tudáshálózatának központi szereplői kivétel nélkül segítséget kérő vállalkozások, vagyis több a kifelé, mint a befelé irányuló kapcsolatuk. Tovább árnyalja a képet, ha összevetjük az innovativitást a külföldi kapcsolatok számával. Egyedül a B8 vállalkozás jelenik meg mindkét hálóban magas értékkel, míg a B10, B11, B12 vállalkozások a hálózat legkevesebb külföldi kapcsolatával rendelkező szervezetei.

A kapcsolatok irányultsága és a külföldi kapcsolatok száma alapján az látható, hogy a magasabb innovativitással rendelkező vállalkozások elsősorban saját belső erőforrásaikra, kompetenciáikra építenek. Mindezt megerősíti, hogy a B10, B11, B12 vállalkozások költségszerkezetét szinte teljes egészében a K+Fköltségek adják (1. táblázat). A B8 vállalkozás kivétel, ahol a K+F-költségek aránya mindössze $25 \%$. Ugyanakkor ennek a vállalkozásnak van a második legtöbb külföldi kapcsolata a hálózatban, így vélhetően ez a vállalkozás hiányzó belső kompetenciáit külső tudásforrásokkal egészíti ki.

Összességben bár a Biopolisz program innovációorientált biotechnológiai klaszter kialakítását tűzte ki célul, a helyi vállalkozások nagyobb része nem vagy alig rendelkezik innovatív termékhez/szolgáltatáshoz kapcsolódó árbevétellel, az élenjáró vállalkozások a helyi tudáshálózat periferikus szereplói.

Végül a hálózati pozíció és a vállalkozások térségen kívüli jövedelemszerző képessége között kerestünk összefüggést, melyet az exportorientáltsággal mértünk (3. ábra). A biotechnológiára jellemző erős exportorientáltság és a pólusprogram nemzetközileg versenyképes klaszterek támogatására vonatkozó célkitűzése ellenére alig néhány szervezet folytat exporttevékenységet. A hálózat alapján elmondható, hogy az exportáló cégek jobbára a több helyi kapcsolattal

3. ábra: Szegedi biotechnológiai vállalkozások exporttevékenysége és tudáshálózati pozíciója Export activity and network position of the biotechnological firms in Szeged

(B1)

(B7)

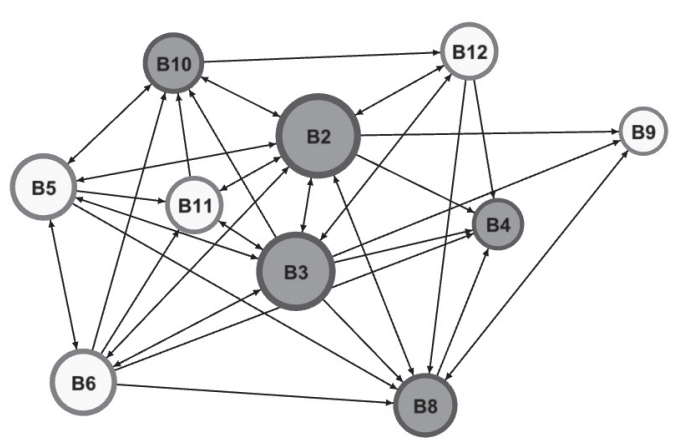

Megjegyzés: A csomópontok mérete azok fokszámával arányos, míg színük az exportárbevétel arányát reprezentálja (szürke: exportáló vállalkozás; fehér: vállalkozás exporttevékenység nélkül). 
rendelkező idősebb vállalkozások. Azonban az exportáló cégek között is jelentős különbségek mutatkoznak. Míg a B8 vállalkozás teljes mértékben külföldre értékesíti termékeit és szolgáltatásait, a többi cég csupán 10-15\% körüli exportértékesítéssel rendelkezik. A B8 vállalkozás azonban a hálózat kevésbé központi szereplője, annak ellenére, hogy mindhárom vizsgált dimenzióban jól teljesít és a helyi iparág fó szektorális fókuszát adó gyógyszeriparhoz kapcsolódik. Bár exporttevékenysége és külföldi kapcsolatai révén számos, térségen kívüli szereplővel folytat együttműködést, amelyektől új tudást szerezhetne, ez a tudás nem vagy alig integrálódik a helyi térségbe.

A szegedi biotechnológiai vállalkozások tudáshálózatát vizsgálva összességében elmondható, hogy relatíve sűrü hálózatról beszélhetünk. Ennek ellenére a hálózat központi szereplöi nem kifejezetten olyan vállalkozások, amelyek a Biopolisz programban meghatározott célok elérését segíthetnék elő. A külföldi kapcsolatokban és az innovativitásban élenjáró vállalati szereplők a hálózat perifériáján helyezkednek el. Így a nemzetközileg versenyképes és innovatív klaszter kialakulásához szükséges térségen belüli és kívüli tudás korlátozottan érhető el a helyi iparág más szereplői számára. A térségen kívüli jövedelemvonzó képességről azt láthatjuk, hogy kevés vállalkozás folytat exporttevékenységet, és még kevesebb azok száma, amelyek innovatív termékeiket vagy szolgáltatásaikat külföldi piacokra viszik. Ugyanakkor az exporttevékenységet folytató vállalkozások többsége a hálózat központi szereplője, ami arra utal, hogy a helyi iparágon belül fontosabb az üzleti jellegű kiválóság, mint a tudáshoz kapcsolódó előnyök.

\section{Következtetések}

A pólusprogram az innovatív, exportorientált, nemzetközileg versenyképes klaszterek támogatását tűzte ki célul, amitől a pólusvárosok tágabb térségének gazdasági fellendülését is várták. A fejlesztési program keretében Szegeden a biotechnológián alapuló iparágak fejlesztését jelölték ki, amelyet a Biopolisz program keretezett. Tanulmányunkban a szegedi biotechnológiai cégek közötti tudásáramlás kapcsolatrendszerét térképeztük fel, hogy a hálózati mintázatok vizsgálata révén értékeljük a Biopolisz programot és annak célkitűzéseit.

A program legfőbb célkitűzése az volt, hogy egy biotechnológiára épülő, tudásintenzív, magas hozzáadott értékkel rendelkező gazdaságot hozzon létre a térségben, helyi tudásintenzív kis- és középvállalatok, kutatóintézetek és biotechnológiai nagyvállalatok kihelyezett részlegeinek együttmüködésére építve.

A tudáshálózat feltérképezése révén bemutattuk, hogy a szegedi biotechnológiai cégek között csupán egy kis méretű, relatíve sűrü, de széteső kapcsolatrendszerről beszélhetünk. Biotechnológiai nagyvállalatot alig találunk a térségben, sőt a válaszadó vállalkozások közül kettő teljesen elszigetelt szereplője a térségi iparágnak. 
A döntően nem high-tech tevékenységeket koncentráló térségekben egy biotechnológiai klaszter kialakításához és kezdeti növekedéséhez az intenzív helyi tudásátadáson alapuló kapcsolatok mellett a térségen kívülről érkező tudásra is szükség van (Trippl, Tödtling 2007). A hálózati szerkezet és a külföldi kapcsolatok vizsgálata során azonban azt láthattuk, hogy a számos külföldi kapcsolattal rendelkező vállalkozás nem rendelkezik arányosan több helyi kapcsolattal, így a térségen kívüli új tudás helyi terjedése nehézkes.

A Biopolisz program célkitűzéseinek a vállalkozások innovációorientáltsága szerves részét képezte. Ezzel szemben a kutatásunk arra világított rá, hogy a helyi vállalkozások nagyobb része nem vagy alig rendelkezik innovatív termékhez vagy szolgáltatáshoz kapcsolódó árbevétellel, illetve az ebben élenjáró vállalkozások a helyi tudáshálózat periferikus szereplői, így az értékes tudás helyi áramlása korlátozottan valósulhat meg.

A Biopolisz program másik fö célkitűzése a biotechnológiai vállalkozások térségen kívüli jövedelemszerző képességének növelése volt, mellyel a foglalkoztatottság bővülését kívánták elérni. A térségen kívüli jövedelemszerző képességet a vállalkozások exporttevékenységének segítségével vizsgáltuk, amiből kiderült, hogy az exportképes vállalkozások száma a térségben jelenleg nagyon alacsony és döntően a legtöbb helyi kapcsolattal, valamint a legtöbb foglalkoztatottal rendelkező cégek képesek csak külföldre értékesíteni. Közöttük viszont elvétve találunk olyan vállalkozást, amely innovatív termékeit vagy szolgáltatásait külföldi piacokon értékesíti.

Jelenleg a szegedi biotechnológiát döntően innovatív, tudásintenzív tevékenységet folytató kis- és középvállalkozások alkotják, azonban a tudáshálózat feltérképezése és elemzése rávilágított arra, hogy egy potenciális klaszterhez hiányzik a kritikus tömeg, az együttmúködés, valamint a kapcsolati beágyazódottság. A kiemelt támogatás és figyelem ellenére az iparág kevésbé képes kihasználni a térbeli koncentráció és a kedvező helyi adottságok nyújtotta előnyöket. A Biopolisz programban kijelölt célok csak mérsékelten valósultak meg, ugyanis gyakran a megvalósításukra kijelölt eszközök nem a célokat szolgálták: az informális kapcsolatok erősítése csekély figyelmet kapott, míg a földrajzi koncentráció ösztönzését pusztán az infrastruktúra fejlesztésével képzelték el.

Közel tíz évvel a Biopolisz program elindulása után elmondható, hogy a biotechnológiától várt gazdasági fellendülés, a térség versenyképességének javulása csak mérsékelten következett be. Csongrád megye versenyképessége a visegrádi országok térségeihez mérten továbbra is gyenge (Lengyel 2016). Véleményünk szerint a hálózat feltérképezése rávilágított arra, hogy a helyi tudásáramlásból és tudástúlcsordulásból származó fontos pozitív hatások csupán korlátozottan jelennek meg, annak ellenére, hogy a Biopolisz program erősen épített ezekre.

Esettanulmányokon alapuló kutatásunk számos korláttal rendelkezik, valamint további vizsgálati irányokat is felkínál. Elemzésünk körébe csupán a TEÁOR'08 72.11 Biotechnológiai kutatás, fejlesztés fó tevékenységgel rendelkező szegedi szervezeteket vontuk be, ami elképzelhető, hogy nem fedi le az 
összes, biotechnológiai kutatási szolgáltatásokkal foglalkozó céget. Az alkalmazott módszertan nem teszi lehetővé a kapcsolatok minőségének mélyebb elemzését, ami tovább árnyalhatná az együttműködések sikerességének megítélését (Hetesi, Vilmányi 2010). Továbbá vizsgálatunk cégek közötti kapcsolatok elemzésére vállalkozott, amelynél pontosabb képet nyújthatna a személyek közötti kapcsolatok feltárása. Mindazonáltal kutatásunk felhívta a figyelmet arra, hogy a helyi hálózatok feltérképezése több szempontból is hasznos lehet a térségi gazdaságfejlesztési tervek elkészítése során, így a hálózatelemzés gyakorlati alkalmazása a térségfejlesztés egyik fontos eszközévé válhat a jövőben.

\section{Köszönetnyilvánítás}

A szerzők köszönettel tartoznak Klepács Angéla mesterszakos hallgatónak az adatgyüjtésben való segítségnyújtásáért. Hálásak vagyunk a hasznos tanácsokért a Szegedi Tudományegyetem Közgazdaságtani és Gazdaságfejlesztési Intézet kollégáinak. A kutatást az EFOP-3.6.1-16-2016-00008 azonosító számú, EUtársfinanszírozású projekt támogatta. Juhász Sándor köszönettel tartozik az Emberi Erőforrások Minisztériuma ÚNKP-18-3 kódszámú Új Nemzeti Kiválóság Programjának támogatásáért.

\section{Irodalom}

96/2005. (XII. 25.) országgyülési határozat az Országos Fejlesztéspolitikai Koncepcióról. https://mkogy. jogtar.hu/jogszabaly?docid=a05h0096.0GY (Letöltés: 2016. november 15.)

Audretsch, D., Feldman, M. P. (1996): R\&D spillovers and the geography of innovation and production. American Economic Review, 3., 630-640.

Barta Gy., Lengyel B. (2007): Budapest mint fejlesztési pólus - a fővárosi elképzelések. Magyar Tudomány, 6., 759-769.

Bathelt, H., Malmberg, A., Maskell, P. (2004): Clusters and knowledge: local buzz, global pipelines and the process of knowledge creation. Progress in Human Geography, 1., 31-56. http://doi.org/c7gzg8

Borgatti, S. P., Mehra, A., Brass, D. J., Labiance, G. (2009): Network analysis in the social sciences. Science, 323., 892-895. http://doi.org/ffm5h3

Boschma, R. (2005): Proximity and innovation: A critical assessment. Regional Studies, 1., 61-74. http://doi.org/dbmh2k

Boschma, R. A., Ter Wal, A. L. J. (2007): Knowledge networks and innovative performance in an industrial district: The case of a footwear district in the south of Italy. Industry and Innovation, 2., 177-199. http://doi.org/cdnc23

Boudeville, J-R. (1966): Problems of regional economic planning. Edinburgh University Press, Edinburgh

Dusek T., Kotosz B. (2016): Területi statisztika. Akadémiai Kiadó, Budapest

EC (2014): The Community Innovation Survey 2014. European Council. https://circabc.europa.eu/ faces/jsp/extension/wai/navigation/container.jsp (Letöltés: 2016. november 15.)

Faragó L., Lux G. (2014): Kurrens portéka vagy múzeumi tárgy? Növekedési pólusok és iparági körzetek a fejlesztéspolitikában. Tér és Társadalom, 28., 11-30. http://doi.org/cwxs

Fekete J. (2008): Új fejlesztési stratégiák, pólusok. Társadalomkutatás, 4., 495-516. http://doi.org/dg4ghz

Feldman, M. (2001): Where science comes to life: university bioscience, commercial spin-offs, and regional economic development. Journal of Comparative Policy Analysis: Research and Practice, 2., 345-361. http://doi.org/c839vt 
Giuliani, E. (2007): The selective nature of knowledge networks in clusters: evidence from the wine industry. Journal of Economic Geography, 2., 139-168. http://doi.org/fsjwtg

Giuliani, E. (2010): Clusters, networks and economic development: an evolutionary economics perspective. In: Boschma, R., Martin, R. (eds.): The handbook of evolutionary economic geography, Edward Elgar, Cheltenham, Northampton, 261-279. http://doi.org/cwxt

Giuliani, E., Bell, M. (2005): The micro-determinants of meso-level learning and innovation: evidence from a Chilean wine cluster. Research Policy, 1., 47-68. http://doi.org/bxb5fz

Hetesi E., Vilmányi M. (2012): A dinamikus kapcsolati képességek és a lojalitás szerepe a szervezetközi kapcsolatokban. Competitio, 11., 2., 76-93.

Jaffe, A. B., Trajtenberg, M., Henderson, R. (1993): Geographic localization of knowledge spillovers as evidence from patent citations. Quarterly Journal of Economics, 3., 577-598. http://doi.org/dbkb5c

Juhász S., Elekes Z., Gyurkovics J. (2016): A tudáshálózatok időbeli változásának vizsgálati lehetőségei. Közgazdasági Szemle, 12., 1375-1388. http://doi.org/cwxv

Juhász S., Lengyel B. (2016a): Kik formálják a klasztereket? Egy helyi tudáshálózat elemzése. Területi Statisztika, 1, 45-65. http://doi.org/cwxw

Juhász S., Lengyel B. (2016b): Tie creation versus tie persistence in cluster knowledge networks. Papers in Evolutionary Economic Geography, 16.13.

KSH (2010): Szegedi Fejlesztési Pólus. Központi Statisztikai Hivatal. http://www.ksh.hu/docs/hun/xttp/ idoszaki/regiok/szegedpolus.pdf (Letöltés: 2017. április 27.)

Lengyel I. (2007): Fejlesztési pólusok, mint a tudásalapú gazdaság kapuvárosai. Magyar Tudomány, 6., 749-758.

Lengyel I. (2016): A kutatás-fejlesztés és a versenyképesség térbeli összefüggései a visegrádi országokban. Tér és Társadalom, 4., 71-87. http://doi.org/cjwh

Lengyel I., Fenyővári Zs., Nagy B. (2012): A közelség szerepének újraértelmezése az innovatív üzleti kapcsolatokban. Vezetéstudomány, 3., 19-29.

Lengyel I., Rechnitzer, J. (2004): Regionális gazdaságtan. Dialóg Campus Kiadó, Budapest, Pécs

Marshall, A. (1920): Principles of economics. An introductory volume. MacMillan, London

Maskell, P., Malmberg, A. (1999): Localised learning and industrial competitiveness. Cambridge Journal of Economics, 2., 167-185. http://doi.org/b6r7n7

Morrison, A. (2008): Gatekeepers of knowledge within industrial districts: who they are, how they interact. Regional Studies, 6., 817-835. http://doi.org/c9kjft

Pólus Programiroda (2008): Pólus Klaszter Kézikönyv. Pólus Programiroda Kht., Budapest https://www.palyazat.gov.hu/doc/1255 (Letöltés: 2018. augusztus 10.)

Porter, M. E. (1990): The competitive advantage of nations. Macmillan, London http://doi.org/bss3

Schulz G. (2012): A biotechnológia klaszteresedésének lehetőségei Szegeden. In: Bajmócy Z., Lengyel I., Málovics Gy. (szerk.): Regionális innovációs képesség, versenyképesség és fenntarthatóság. JATEPress, Szeged, 132-148.

Szakálné Kanó, I., Vas, Zs. (2013): Spatial distribution of knowledge-intensive industries in Hungary. Transition Studies Review, 4., 431-444. http://doi.org/cwxx

Szeged Pólus (2005): Szeged biopolisz növekedési pólusprogram koncepciója. Szeged Pólus Fejlesztési Nonprofit Kft., Szeged http://www.szegedpolus.hu/images/stories/dokumentumtar/ biopoliszkoncepcio.pdf (Letöltés: 2017. április 27.)

Ter Wal, A. L. J., Boschma, R. (2009): Applying social network analysis in economic geography: framing some key analytic issues. The Annals of Regional Science, 3., 739-756. http://doi.org/fm7btt

Trippl, M., Tödtling, F. (2007): Developing biotechnology clusters in non-high technology regions - The case of Austria. Industry and Innovation, 1., 47-67. http://doi.org/fr46vf

Varga A. (2004): Az egyetemi kutatások regionális gazdasági hatásai a nemzetközi szakirodalom tükrében. Közgazdasági Szemle, 3., 259-275.

Wasserman, S., Faust, K. (1994): Social network analysis: Methods and applications. Cambridge University Press, Cambridge http://doi.org/ccn2

Zucker, L., Darby, M., Brewer, M. (1998): Intellectual human capital and the birth of the U.S. biotechnology enterprises. American Economic Review, 1., 290-306. 